\title{
STRATEGIES OF THE SMALL-SCALE FISHERIES ON THE CENTRAL AMAZON FLOODPLAIN
}

\author{
Carlos Edwar de Carvalho FREITAS, Vandick da Silva BATISTA, \\ Antonio José INHAMUNS
}

\begin{abstract}
A multivariate approach was applied to data of small-scale fisheries developed in Central Amazon, using information about catch composition, environment, fishing gear and season of the hydrological cycle. The correspondence analysis demonstrated to be a good tool for the analysis related multispecies fisheries. The analysis identified patterns of use of fisheries resources by the riverine communities, showing the correlation between the environmental factors and the fishing strategy for the capture of target fish species, indicating the high level of empiric knowledge about the environment and fisheries.
\end{abstract}

Key-words: small-scale fisheries, Central Amazon, multivariate analysis, patterns.

\section{Estratégias da pesca de subsistência nas várzeas da Amazônia Central}

Resumo - Uma abordagem multivariada foi desenvolvida com informações da pesca de subsistência na Amazônia Central, usando dados de composição das capturas, do ambiente, do aparelho de pesca e da época do ciclo hidrológico. A análise de correspondência empregada demonstrou ser uma boa opção para a identificação de padrões de uso dos recursos pesqueiros pelas comunidades ribeirinhas, evidenciando as correlações existentes entre os fatores ambientais e a estratégia de pesca, confirmando a hipótese de que estas comunidades possuem um elevado conhecimento empírico do ambiente em que vivem e da pesca.

Palavras-chaves: pesca de subsistência, Amazônia Central, análise multivariada, padrões.

\section{INTRODUCTION}

The importance of the fishing activity in the Amazon basin can be observing by the high average fish consumption in the region, higher than other Brazilian regions as well as other countries with a strong fishing tradition: $167 \mathrm{~g} / \mathrm{per}$ capita.day, at Manaus city, capital of the Amazon State, for the low income class (Schrimpton \& Giugliano, 1979), $194 \mathrm{~g} /$ per capita.day, at Itacoatiara city and it rural area (Smith, 1979), $369 \mathrm{~g} / \mathrm{per}$ capita.day for the people who live along banks of Lago Grande de Monte Alegre, rural area of the Pará State (Cerdeira et al., 1977) and above $500 \mathrm{~g} / \mathrm{per}$ capita.day, in the rural area of the Central Amazon (Batista et al., 1998a). Presently, five distinct fisheries coexist in the Amazon basin: small-scale fishery for subsistence, multispecific commercial fishery towards the local market, monospecific commercial fishery towards exportation, fisheries in reservoirs and ornamental fishery.

Departamento de Ciências Pesqueiras, Faculdade de Ciências Agrárias - Universidade Federal do Amazonas, Av. Gen. Rodrigo Otávio Ramos Jordão, 3000 - Cep: 69077-000, Manaus Amazonas - Brasil, edwar@argo.com.br

Departamento de Ciências Pesqueiras, Faculdade de Ciências Agrárias - Universidade Federal do Amazonas, Av. Gen. Rodrigo Otávio Ramos Jordão, 3000 - Cep: 69077-000, Manaus Amazonas - Brasil, tchoni@uol.com.br

Departamento de Ciências Pesqueiras, Faculdade de Ciências Agrárias - Universidade Federal do Amazonas, Av. Gen. Rodrigo Otávio Ramos Jordão, 3000 - Cep: 69077-000, Manaus Amazonas-Brasil, inhamuns@manaus.br 
The word subsistence its already been used in fishery literature to define the traditional use of fishing resources by social formations dependent on that resource, including family groups, small villages, ethnic substructures and other small size structures. The dependence includes physical survival, maintenance of traditional cultures and the persistence of the social structures (Muth, 1996). The rural people of amazonian region are distributed along bank rivers, building their houses on the land patch know as high floodplain. They farm the land and raise small animals to generate economic surplus and they present strong dependence on fish as protein source (Batista et al., 1998b).

For several decades the management of the world fishing has been done on basis of individual stocks evaluation. The multispecific characteristics of the Amazon fishing and the unknowledgement of dynamic population of most exploited species do not allow the general use of traditional evaluation models (Petrere Jr., 1983a; Isaac \& Ruffino, 1996; Isaac et al., 1996). Other approaches aimed at obtaining estimates of the Amazon basin fishing potential and/or develop models to identify the factors which explain the captures have been developed (Bayley, 1981; Petrere Jr., 1983b).

The use of multivariate techniques is relatively recent in the fishing management literature. Rocha et al. (1995) discuss the application of Principal Component Analysis for study multispecific fisheries and observe its feasibility as exploratory analysis. Isaac et al. (1996) analyzed the artisanal fishing at the Low Amazon, using landings information in Santarém city, through the Factors Analysis to correlate groups of species along with exploitation strategies.

This paper presents a description of small-scale fisheries for subsistence at the Central Amazon, analyzed through correspondence analysis which do an exploratory analysis the patterns of catch composition in relation to the main factors involved in the activity.

\section{MATERIAL AND METHODS \\ Study area and information collected}

Data on subsistence fishing of the riverine people were collected in floodplain communities located at four subregions of the Central Amazon (Fig. 1), Pesqueiro Lake, Paciência Island, Aruanã Coast and Marimba Coast. The environmental characteristics and economy of these sub-regions its already been described by Batista et al.(1998a) and Freitas \& Batista (1999).

During 1993, 1,466 interviews were taken in floodplain communities of the Central Amazon, 152 at Pesqueiro Lake region, 300 at area of the Aruanã Coast, 432 at Paciência Island and 532 at the region of the Marimba Coast. The interviews were made with standard questionnaires and using a simple random procedure (Cochran, 1977) to choice the communities and the house for each work day.

\section{The multivariate analysis}

With the proposal to identify patterns of fisheries resources use by 
riverine people of Central Amazon floodplain and represent then on the restrict number of axes, we use a correspondence analysis (Braak, 1995). This analysis have couple transformation and to make use of $\mathrm{c}^{2}$ measures and it consent that the information to be quantitative, qualitative and mixed (Braak, 1995). The analysis was developed from three molds: at the first mold included sazonality $\mathrm{x}$ catch composition $\mathrm{x}$ four sub-regions, the second included fishing gear $\mathrm{x}$ catch composition $\mathrm{x}$ four sub-regions and the third included environment $x$ catch composition $\mathrm{x}$ four sub-regions.

\section{RESULTS}

The Correspondence Analysis that we used obtained index of inertia
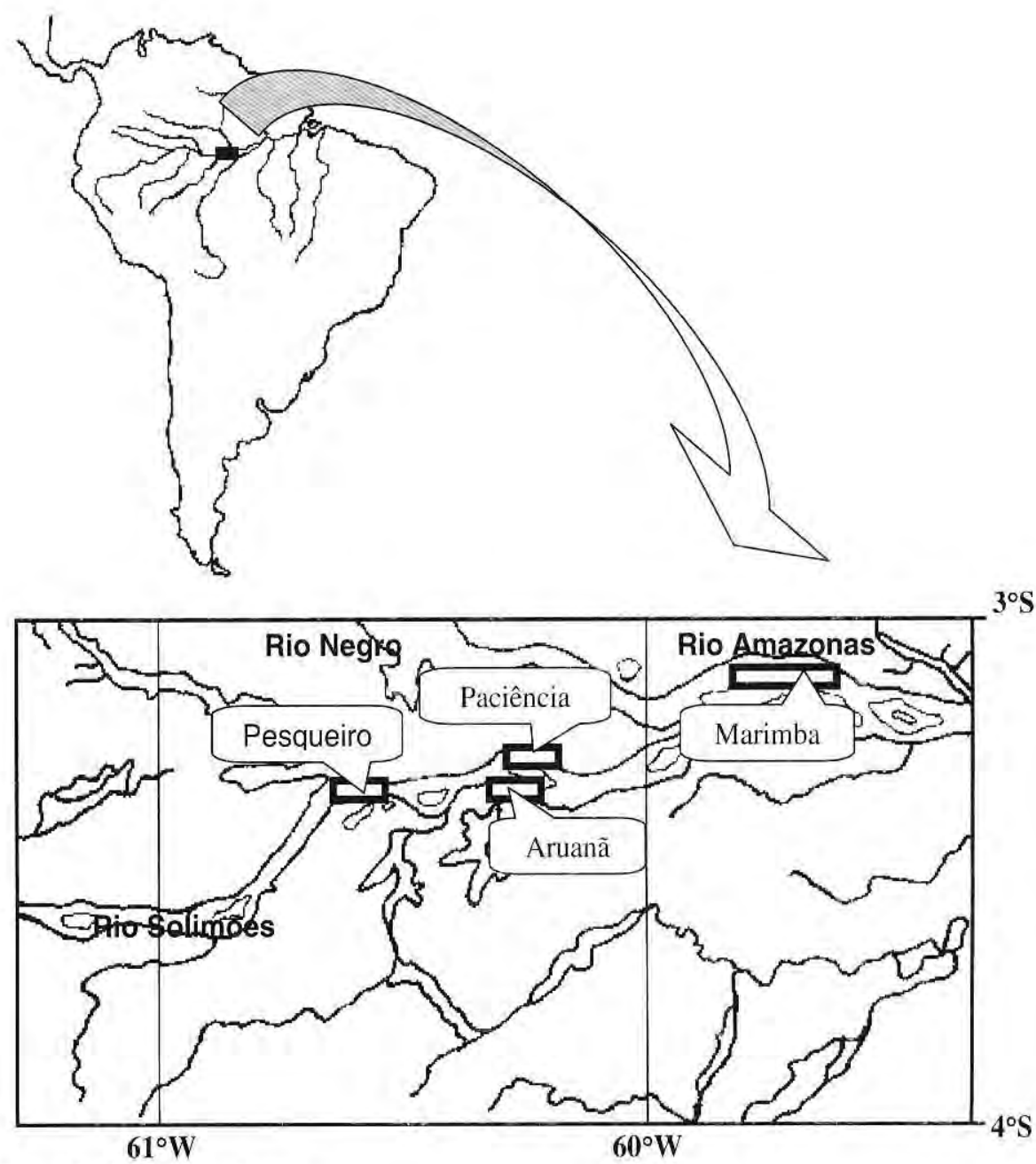

Figure 1. Map of study area. 
of $95,79 \%, 93,15 \%$ and $90,00 \%$, respectively, for two first orthogonal axes, indicating the high robustness of this analysis. Gauch Jr. (1982) recommend the use of three criterion to evaluate the results of ordination techniques: (i) efficiency to reduce the dimension of whole information and or in the production of identifiable patterns; (i) application for several kinds of data avoiding the lost of information; and, (iii) facility of use. The results show that criterion proposed was reached, with identifiable patterns produced without relevant information lost.

The correspondence analysis using information of the fishing gear resulted in two interpretable axes. The first axis presented $65,19 \%$ of inertia and it separates gears of more restricted use, as harpoon and rods in the ends, maintaining the gears of generalist use, as gillnets and nets in the central part of the graph (Fig. 2).

The correspondence analysis identified a seasonal pattern in the fisheries, isolating the drought period, in the left portion of the first axis $(80,77 \%$ of inertia), and the flooding period, in the right portion of this same axis. The fishery made in the flood and in the falling exhibit captures with averages compositions that include species and abundance similar to two other periods of the hydrological cycle (Fig. 3).

Using the information of fishing environment, the Correspondence Analysis considers that the catch composition of the fisheries made in riv-

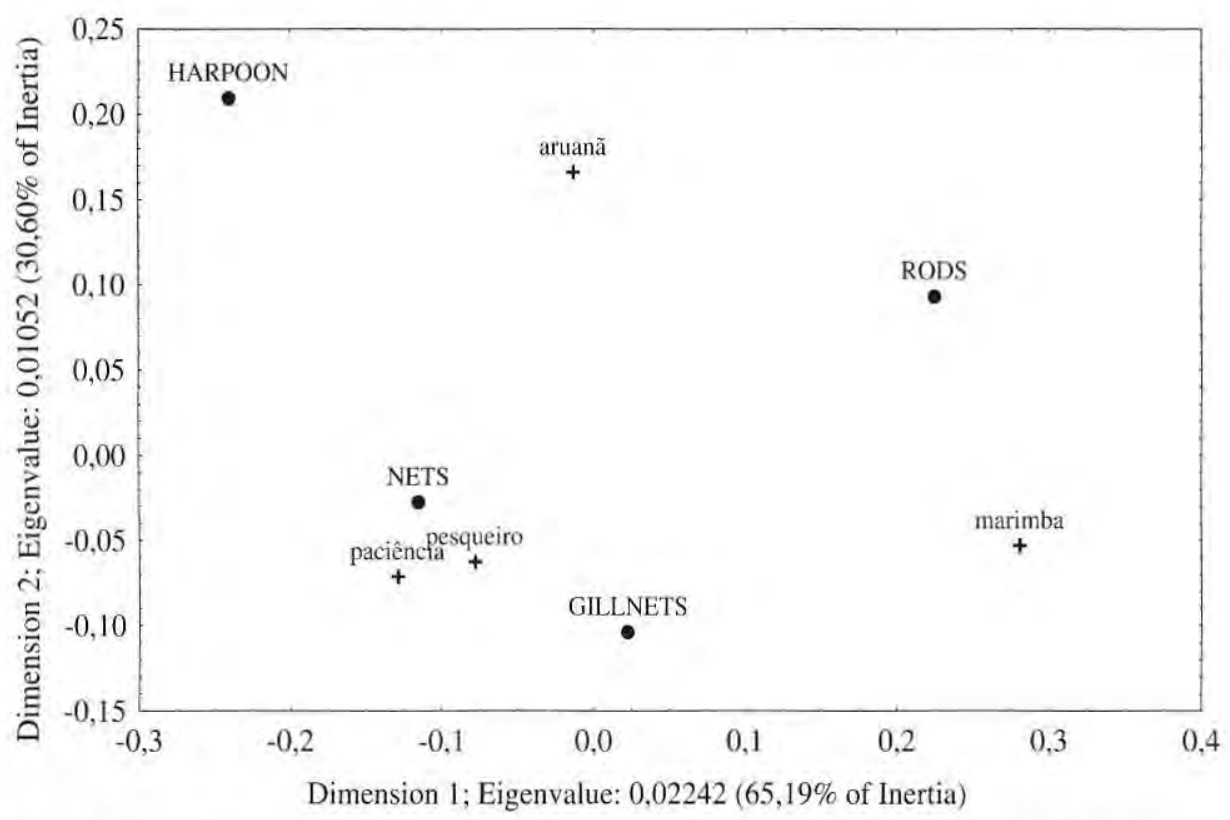

Figure 2. Graph of two first dimensions of Correspondence Analysis with data of fishing gear. 
ers they are quite different from the fisheries done at Lakes, the first axis has $87,84 \%$ of inertia. The fisheries accomplished at the Igapó its result in more generalist compositions (Fig. 4).

\section{DISCUSSION}

The results confirm the hypothesis proposed by Meshkat (1960), he points that amazonian fishermen possesses a

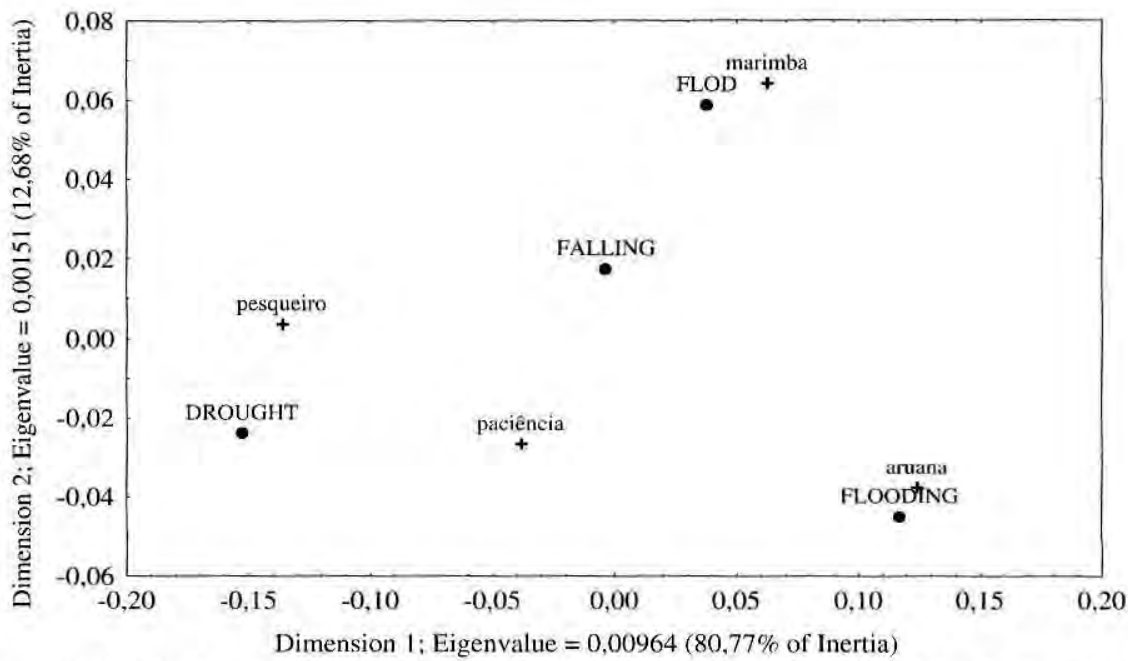

Figure 3. Graph of two first dimensions of Correspondence Analysis with data of season of hydrological cycle.

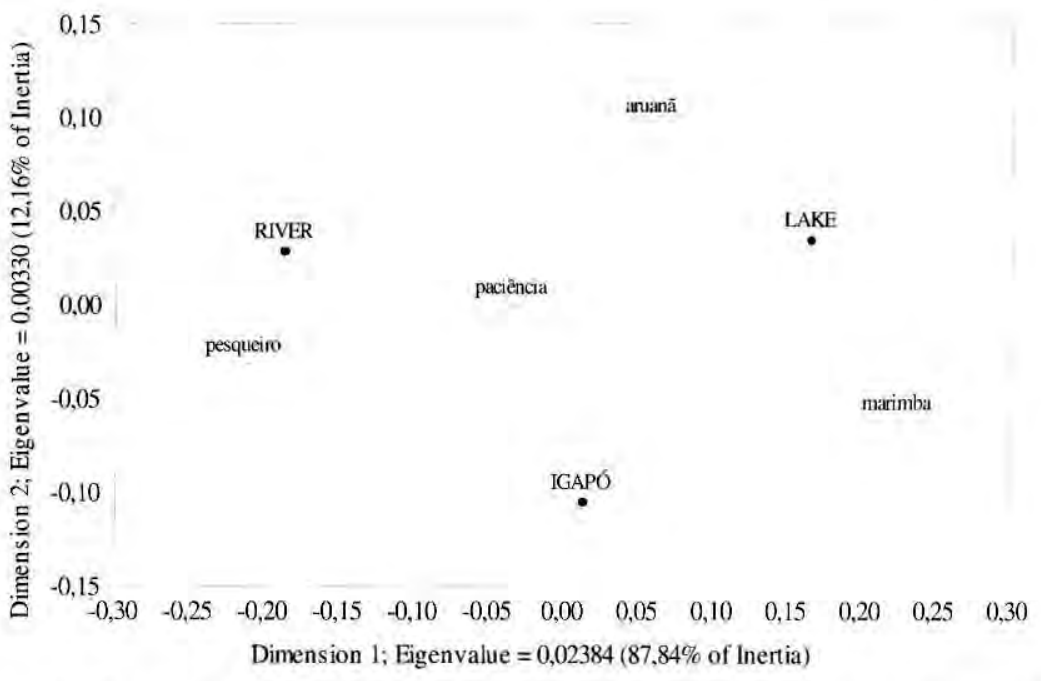

Figure 4. Graph of two first dimensions of the Correspondence Analysis with data of environment. 
great ability in fishing gear use due a high empiric knowledge about the fishing environment and the fish. The more generalist use of gillnets can to be explained by diversity of work form this fishing gear. In the Amazon Basin, the gillnets are used as passive gear, fixed with sticks or tied to submerged vegetation, on lakes during the drought season and at flooded forest during the flood season; and as active gear, on the rivers, drifting, perpendicularly on the surface water body, tied to a boat (Petrere Jr., 1978; Smith, 1979; Batista et al., 1998a, b). The nets are used all year round, but they present spatial restrictions in the flooded forest due the great amount of submerged vegetation.

The fisheries are more generalists at falling and flood seasons than during the drought and flooding seasons, probably due the availability of habitats allowing the use of several kinds of fishing gears (Petrere Jr., 1978; Merona, 1993). The predominance of fisheries with nets, on rivers, at drought season on Pesqueiro Lake and Paciência Island sub-regions is a good example of the interaction between the environment and the riverine people who live in Central Amazon region. During this phase of the hydrological cycle, the lakes was remain closed to boats and the fisheries it happens predominantelly on the rivers, where nets are more effectives. Other good example is the predominance of fisheries with rods during the flood season at Marimba sub-region, since these fisheries are developed in the flooded forest that have constraints to the use of other gears as nets.

The predominance of certain gears in the small-scale fisheries of Central Amazon region, the seasonality in the use of these gears, in the catch composition and in the exploited environments has already been determined in previous studies (McGrath et al., 1994; Batista et al., 1998a; Freitas \& Batista, 1999). However, the observance of factors interaction highlights the existence of strategies of natural resources exploitation and is an aspect few studied.

As Batista et al. (1998a), we concluded that there are many spatial and temporal variations in the patterns of capture use which are linked with the environment characteristics The patterns of exploitation must be taken into consideration for the elaboration and implantation of fishing management proposals in the Amazon Basin, because its strong relation with the sustainability of the whole system. Our conclusions are really just to go beyond the traditional recommendations to implement certain types of fisheries regulation, that will help to plug the gaps that generally result from the traditional approach.

\section{Literature Cited}

Batista, V.S.; Silva, A.J.I.; Freitas, C.E.C.; Freire-Brasil, D. 1998a. Characterization of the fishery in riverine communities in the Low-Solimões/High-Amazon region. Fisheries Management and Ecology, 5:101-117.

Batista, V.S.; Freitas, C.E.C.; Silva, A.J.I.; Freire-Brasil, D, 1998b. Os ribeirinhos e a pesca nas várzeas da Amazônia central. Revista UA Série Ciências Agrärias. 7(1-2):57-75.

Bayley, P.B. 1981. Fish yield from the Amazon in Brazil: comparisons with African river yields and management possibilities. Transactions of the American Fisheries 
Society, 110:351-359.

Braak, C.J.F. ter 1995. Ordination. In Jongman, R.H.G.; Braak, C.J.F. ter; Tongeren, O.F.R. van (Eds.) data Analysis in Community and Landscape Ecology. Bambridge University Press, Cambridge, p. $91-173$.

Cerdeira, R.G.P.; Ruffino, M.L. \& Isaac, V.J. 1997. Consumo de pescado e outros alimentos pela população ribeirinha do Lago Grande de Monte Alegre, PA. Brasil. Acta Amazonica, 27(3):213-228.

Cochran, W.G. 1977. Sampling Techniques. John Wiley \& Sons Publ., 428 p.

Freitas, C.E.C.; Batista, V.S. 1999. A pesca e as populações ribeirinhas da Amazônia Central. Brazilian Journal of Ecology, 3(2):1-15.

Gauch Jr., H.G. 1982. Multivariate Analysis in Community Ecology. Cambridge University Press, Cambridge, 298 p.

Isaac, V.J.; Ruffino, M.L. 1996. Population dynamics of tambaqui Colossoma macropomum Cuvier, 1818, in the lower Amazon, Brazil. Fisheries Management and Ecology, 3:315-333.

Isaac, V.J.; Milstein, A.; Ruffino, M.L. 1996. A pesca artesanal no Baixo Amazonas: análise multivariada da captura por espécie. Acta Amazonica, 26(3):185-208.

McGrath, D.G.; Castro, F.; Futemma, C. 1994. Reservas de lago e o manejo comunitário da pesca no Baixo Amazonas: Uma avaliação preliminar. In D'Incao, M.A.; Silveira, I.M. (Eds.) Amazônia e a Crise da Modernização. Publicações do Museu Paraense Emílio Goeldi, Belém, p. 389-402.

Merona, B. de 1993, pesca e ecologia dos recursos aquáticos na Amazônia. In Furtado, L.G.; Mello, A.F.; Leitão, W.. (Eds.) Povos das Águas: Realidades e Perspectivas na Amazônia. Museu Paraense Emílio Goeldi, Belém, p. $159-185$.
Meschkat, A. 1960. Reports to the government of Brazil on the fisheries of the Amazon Region. FAO Report 1305. BRA/Te/Fi, 76p.

Muth, R. M. 1996. Subsistence and artisanal fisheries policy: an international assessment. In Meyer, R.M.; Zhang, C.; Windsor, M.L.; McCay, B.J.; Hushak, L.J.; Muth, R.M. (Eds.) Proceedings of the World Fisheries Congress - Theme 2. Oxford \& IBH Publishing Co. Pvt. Ltd., New Delhi, p. 76-82.

Petrere Jr., M. 1978. Pesca e esforço de pesca no Estado do Amazonas. II. Locais, aparelhos de captura e estatisticas de desembarque. Acta Amazonica, 8(supl. 2), $54 \mathrm{p}$.

Petrere Jr., M. 1983a. Yield per recruit of tambaqui, Colossoma macropomum Cuvier, in the Amazonas State, Brazil. Journal of Fish Biology, 22:133-144.

Petrere Jr., M. 1983b. Relationships among catches, fishing effort and river morphology for eight rivers in Amazonas State (Brazil) during 1976-1978. Amazoniana, 8:281-296.

Rocha, C.A.S.; Stokes, T.K.; Pope, J.G. 1995. Application of principal component analysis to the study of multispecies fisheries. Ciência e Cultura, 47(1/2):68-75.

Schrimpton, R.; Giugliano, R. 1979. Consumo de alimentos e alguns nutrients em Manaus, 1973-1974. Acta Amazonica, 9(1):117-141.

Smith, N.J.H. 1979. A Pesca no Rio Amazonas. INPA, Manaus - Amazonas, $154 \mathrm{p}$. 